
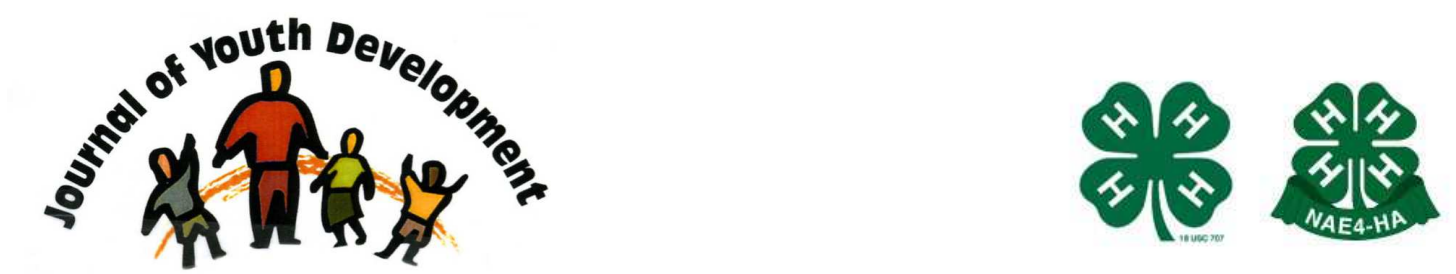

Bridging Research \& Practice

\title{
Making the Best Better: \\ 4-H Staffing Patterns and Trends in the Largest Professional Network in the Nation
}

Kirk A. Astroth

Montana 4-H Center for Youth Development

Montana State University Bozeman, MT

kastroth@montana.edu 


\title{
JOURNAL OF YOUTH DEVELOPMENT \\ bridging research and practice

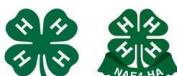

\section{Making the Best Better: \\ 4-H Staffing Patterns and Trends in the Largest Professional Network in the Nation}

Kirk A. Astroth

Montana State University

\begin{abstract}
results are reported in eight areas:
1. profile of respondents;

2. current 4-H staffing structures;

3. staffing trends and changes since 1990;

4. academic degree requirements;

5. compensation levels;

6. academic and other preparation;

7. ideal staffing models; and

8. current and future challenges.
\end{abstract}

Abstract: The results from the National 4-H Headquarters' survey of the 4-H workforce provides baseline data about 4-H staffing, structures in which 4-H professionals work, and salary ranges as reported by state Extension 4-H directors. All 50 states responded to the survey and

The survey revealed that academic training of $4-\mathrm{H}$ professionals and compensation for 4- $\mathrm{H}$ youth workers was higher compared to their counterparts in youth work elsewhere. While funding for 4-H positions has remained stable, there has been an increase in the use of paraprofessionals for program delivery.

\section{Situation}

Today's children spend a significant portion of their lives in non-formal educational settings. While there was been considerable attention devoted to teacher certification and student/teacher ratios in our nation's schools, there has been much less attention focused on the professionals who work in out-of-school programs. 
Yet, these hours are critical to the positive development of youth. With more parents working more hours than ever before, there is a consistent and ever-growing demand for top-quality non-school programs for children and youth. Parents have high hopes and dreams for their children and want to be assured that out-of-school programs are helping their children reach their highest potential.

The demand for after-school programs was documented in the first-ever household survey published by the National Afterschool Alliance. "In U.S. communities today, 14.3 million children take care of themselves after the school day ends, including almost four million middle school students in grades six to eight. Just 6.5 million children are in after school programs but the parents of another 15.3 million children say their children would participate in an afterschool program - if a program were available" (National Afterschool Alliance, 2004, p. 1).

However, high quality after-school programs require well-trained, knowledgeable, optimistic and stable staff. Youth who are able to enjoy consistent, positive relationships with caring adults in high-quality youth development programs tend to do better in life. It's that simple. What isn't simple is finding ways to support the professionals who design and deliver the programs to support our children.

Study after study has documented that one of the most important protective factors in a young person's life is a caring adult. From America's Promise's long-standing emphasis on the five promises, to the recent National Research Council's report on community programs that promote youth development, caring adults make a critical difference in outcomes for our young people (Eccles and Gootman, 2002).

Although several million professionals are estimated to work in youth development, the Annie $\mathrm{E}$. Casey Foundation observed that-

"Youth services is the least documented, least understood and probably the most varied field we studied. There is no national data set on youth workers, or on youth-serving programs..... Much of the data are unreliable and often inaccurate...the lack of good information about youth workers and what they do stands in sharp contrast to the documented benefits of youth programs"(2003, p. 12).

Several recent studies about salaries and benefits of working in human services produce a picture that "is both uplifting and depressing" (Boyle, 2006. p. 22). Youth workers are typically passionate about their mission and their work, but routinely are not provided with adequate compensation to make youth work a viable career. For example, a new study of 1,053 youth workers in eight urban communities found a median salary of about $\$ 25,500$. This level if below what most school teachers are paid. This study also found that 40 percent of those surveyed needed to work a second job just to make ends meet (Yohalem, Pittman and Moore, 2006). Such conditions led one expert to report recently that "human services delivery is reaching a state of crisis" (Light, 2003, p. 1).

While youth work often offers the advantage of flexible work hours, it is also an increasingly demanding field with expectations about skills and abilities that are not met with adequate pay. Most agree-youth work is becoming more complex and demanding, in large part due to 
technology, government reporting requirements and the complicated issues youth themselves bring to youth programs.

Not surprisingly, turnover is high in youth work, so that youth organizations struggle with finding strategies to retain talented youth workers, increase satisfaction and reduce early burnout. In the Brookings survey, 81 percent of those surveyed said that "it is easy to burn out in the work they do" (Light, 2003, p. 6).

\section{Background to the Study}

Youth development occurs from the natural process of growing up. But without help and left to their own devices, some young people cannot successfully make the transition into adulthood from adolescence. Youth development is far too important to be left to chance. That's why professional youth workers are so critical to the community support network for youth development.

Why the concern about the professional youth worker? A 1998 study conducted by the U.S. Department of Education called "Safe and Smart: Making the Afterschool Hours Count for Kids" (1998) cited several factors which are essential for developing first-rate programs that can meet the needs of youth. The key factors identified in this report were low staff-youth ratios, strong involvement of families, effective partnerships within the community, and high-quality staff members.

\section{4-H Youth Professionals}

4-H has one of the most extensive professional networks of any youth serving organization in the nation and understanding more about this organization's staffing would provide important data about a major segment the youth work field.

Clearly, the status, training and compensation for 4-H Extension professionals have been points of discussion for some time. For example, 4-H youth workers were originally dubbed "club agents" and had a lower status than county agricultural agents or home economics agents. 4-H work was referred to as "Junior Extension Work" instead of 4-H (Wessel and Wessel, 1982). In addition, 4-H Extension workers did not have their own professional association until a group of Northeast agents, under the leadership of Don Stiles, banded together and formed the National Association of 4-H Club Agents in 1946. In 1952, 4-H was formally granted equal status with the other divisions of the Extension Service by USDA (Wessel and Wessel, 1982, p. 345). Some would argue, though, that equality for 4-H in comparison to other divisions of Extension has yet to be achieved. For example, $4-\mathrm{H}$ tends to lag behind the other areas in ratio of campus to field faculty (McDowell, 2006).

In the early 1960's, Federal Extension staff conducted a survey of Extension staff and clientele in 13 Western states to learn more about their attitudes toward 4-H work, objectives and methods (Sabrosky, 1963). This study found that 4-H agents had broad educational responsibilities, and the field was viewed as good preparation-but for Extension work with adults, not youth. Some expressed that inexperienced workers would do better in 4-H work than in adult Extension work. Youth work was considered the domain of the less-experienced and least educated. 
In 1984, the National Association of Extension 4-H Agents supported a study of the image of the 4-H professional. This study found that there were wide variations in the image and status of 4- $\mathrm{H}$ professionals across the nation. In addition, there was general agreement that while degrees should not be obtained for the sake of degree attainment, formal educational levels should increase among 4-H professionals. While the image of the 4-H professional was generally positive, the study found concerns related to salary equity, benefits and opportunities for advancement within the Extension system. Finally, this study called upon Extension at all land-grant universities to address questions about faculty status, compensation levels, professional titles and hiring requirements (Gerhard, 1984).

These studies point out that the concern about the status and image of the 4-H professional have been abiding concerns. Since the early 1990's there has been a perceived, yet undocumented, shift in 4-H staffing at the state and county levels. It is widely believed that programs that were once led by Extension 4- $\mathrm{H}$ faculty and staff with undergraduate and graduate degrees are now more likely to be led by para-professionals or program assistants (or other titles) who may have high school diplomas or hold an associate's degree from a two-year college.

If true, this "de-professionalization" of 4-H educators could have a negative impact on the overall health of the 4-H youth development field precisely at a time when other organizations and groups are advocating for a higher level of professionalism in youth development by pushing for national standards and credentials for youth workers. Unfortunately, 4-H youth development specifically, and youth work in general, are already perceived by some as merely "child's play" that can be done by anyone without any specific training or expertise (Astroth, 2003; Astroth, 2004). Such misconceptions devalue youth work as a profession and imply that specialized training is unnecessary to everyday work, let alone to achieving positive youth development outcomes.

However, many in youth development feel that there is a significant connection between high quality youth outcomes and the professional preparation and training of youth workers. In 2001, the National Research Response Task Force identified examining the link between program quality and the professional preparation and training of 4-H professionals as a research priority for the 4-H system (Blyth and Borden, 2003). If these trends cited above are based in reality, there is concern that program quality could be negatively impacted.

\section{Purpose of the Study}

These and other concerns led to an effort to survey all states about current staffing structures that could provide some important baseline data. Information collected from such a survey could inform future directions in 4-H staffing and strengthening program outcomes.

The purpose of this internet-based survey, then, was to gather baseline information about current and past staffing patterns, degree requirements and compensation levels in each state to understand any shifts in staffing responsibilities and emphases since 1990. This benchmark year was selected because the downsizing from the mid-1980's farm and bank crises were behind Extension, and 1990 was before funding from the Federal Children, Youth and Families at Risk (CYFAR) program began which resulted in increased funding for soft-funded staff positions. 


\section{Research Questions}

The following research questions were formulated for this study:

1. What is the current staffing structure in place in each state?

2. What is the current staffing structure in place within districts (if applicable) and counties in each state?

3. How do current staffing structures compare with staffing in 1990 ?

4. What degree requirements exist for $4-\mathrm{H}$ youth workers at various levels of the system?

5. How are 4-H professionals compensated across the system?

6. Are the degree expectations the same or different for $4-\mathrm{H}$ youth workers compared to other Extension professionals?

7. What fields of study or disciplines are the best preparation for youth work in 4-H?

8. What is the best staff configuration for supporting $4-\mathrm{H}$ youth development?

\section{Methodology}

An expert panel of Extension 4-H youth professionals was assembled to help identify and refine appropriate questions for the on-line survey. This group consisted of two national program leaders, a state 4-H program leader, county Extension agents and specialists.

During the summer of 2006, this panel provided feedback and suggestions to question construction and wording. Several versions of the survey were shared with the expert panel until all felt that the survey was ready for administration.

The survey was launched at the end of August 2006 and posted live for approximately 6 weeks. Periodic announcements and appeals were also sent to the state 4- $\mathrm{H}$ program leader list-serve and other lists. In some cases, personal phone calls were made to encourage completion. Some states required 2-3 reminders. Eventually, a 100 percent response rate was obtained.

The survey instrument consisted of a mixture of multiple choice questions and open-ended questions. Unfinished surveys could be completed at a later date, and only one completed survey per person was allowed.

\section{Findings}

Findings from this survey were compiled and analyzed in October and November of 2006. These findings are reported in eight major categories-profile of the respondents, current 4- $\mathrm{H}$ staffing structures, staffing trends and changes, academic degree requirements, compensation levels, academic and other preparation for youth work, ideal staffing models, and challenges to 4-H staffing.

\section{Profile of Respondents}

All fifty states responded to the survey. The largest group of state leaders who participated in the survey is relatively new to their roles. More than one third (37 percent) had been state leaders for only 3-5 years, and 24 percent had been in their position less than 2 years. Twenty percent had 6-10 years of experience as program leaders, 8 percent had 11-15 years of administration experience, and another 12 percent had more than 16 years of experience.

In terms of academic requirements for state leader positions, nearly half of the states (47 percent) required a master's degree, while 51 percent required a doctoral degree, but one state required only a bachelor's degree. 
Those in state 4-H program leader positions tended to have doctoral degrees themselves. Sixty-one percent had terminal degrees, while 33 percent had master's degrees. Just one state 4-H program leader had earned only a bachelor's degree. One state leader was working on a doctoral degree. Two individuals skipped this question.

\section{Current Staffing Structures}

State 4-H Office Staffs. Several questions probed number of state staff FTEs as well as numbers of actual staff as one means of gauging program size-both in hard and soft-funded positions. Total state staff FTE numbers ranged from a low of 0.25 to a high of 21. Total FTEs (both hard and soft-funded positions) at the state office level for all respondents was 399.35. The average number of FTEs per state office is about 8 . The mode was 7 , and the median was also 7 .

The survey also collected information about program coordinators at the state office level. Of those responding to the survey, 30 percent indicated that they did not have such any FTEs in such a position at the state level, while 30 percent said they had one. Nearly twenty percent (10 states) said they had at least 2 FTEs for program coordinators.

District/Area 4-H Staffs. In addition to state level positions, the survey collected data on district or regional program staffing levels. While 76 percent (40 states) reported that they had no such structure in their states, those that had such a level in their system (a total of 10 states) reported widely different structures. Eight percent (4 states) reported having a total of 4 FTEs dedicated to 4-H program leadership at the district or area level. Four states reported having 10 or more FTEs at the district or area level. ${ }^{1}$

When it comes to program coordinators, again the majority of states do not have a district level of programming in their system, so only 10 states reported on these positions. Of those responding, 7 states have no such positions in their district/regional offices. One state has 3 program coordinators at the district level, and one state reported that they have 5 district program coordinators/program assistants. Obviously, program coordinators at the area or district level are neither common nor widespread at the current time.

County 4-H Educators. Extension programming is thought of as primarily delivered at the county level, so not surprisingly 95 percent of states (47) reported having a county-based system in their Extension network. Most (67 percent, or 32 states) have an Extension presence in all counties in their states, but the remainder of states lack an Extension presence in just a small number of counties. In most instances, even where there is no Extension office in a county, there is an Extension presence either through a neighboring county or an Extension 4-H program led by volunteers.

In response to a question about the number of full-time 4-H positions (people who work 100 percent in 4-H youth development), the total number of such positions across the entire system amounted to 1,975 people. When asked how many total county or parish FTEs are dedicated to 4-H programming, this number grew to $2,801.66$ because many agents have multiple

\footnotetext{
${ }^{1}$ Note: Feedback during the data collection process indicated that in one state, at least, this term was confusing. In Missouri, field faculty often have multiple county assignments and are called Regional Specialists but they are not really a middle level of staffing. They have county assignments they are just assigned county-type responsibilities in multiple counties.
} 
programmatic responsibilities of which $4-\mathrm{H}$ is just one of several. ${ }^{2}$ These staff numbers compare with 3,066 counties in the nation.

When asked about the existence of program coordinators/program assistants, this type of position was more common at the county level than at either the district or state level. Fortyfour states indicated that they had such positions at the county level, ranging from a low of one such position to a high of nearly 80 FTEs. When asked about how many FTEs at the county or parish level are filled by 4-H program assistants, para-professionals or program coordinators, the total across the entire system was reported as 1,060.

\section{Staffing Trends and Shifts}

State Level Trends. One of the key questions asked on the survey was about current harddollar state 4-H program FTEs in comparison to 1990. Interestingly, 58 percent of the states replying indicated that their state staff FTE was smaller than in 1990 . However, 28 percent of the states indicated that they had more FTEs now than in 1990. Nine percent had remained the same. Four percent did not know if state staff size had changed over the past 16 years.

When soft-funded positions were examined, more than one-third of states reported no such positions at the state level. Another 28 percent indicated that they had only one such position, 17 percent reported that two such positions existed in their state office, and 9 percent reported that 3 such positions existed. Two states reported that they had 6 such positions on their state staffs. One state reported having more than 10 soft-funded FTE positions.

County Level Trends. In response to how current county staffing levels compare to those in 1990, some states reported having more FTEs because of increased funding, but other states reported having fewer FTEs because of funding cuts. Overall, 48 percent of states have seen a decline in the number of FTEs for $4-\mathrm{H}$, while 28 percent have seen an increase in the number of 4-H FTEs since 1990. Fifteen percent reported that they have stayed the same. Interestingly, 9 percent did not know.

When counting people rather than FTEs, over half (54 percent) of the states reported declines in 4-H agent numbers whereas nearly a third (30 percent) reported that the number of 4-H agent positions has increased since 1990. About 11 percent had stayed the same, and 3 percent did not know.

In 56 percent of the states, the number of para-professional positions has increased at the county level since 1990, whereas the number of such positions has stayed the same in 13 percent of states, and in 13 percent there has been a decline in such positions. Interestingly, 17 percent weren't sure about the shift in such positions. The total number of FTEs filled by program coordinators, para-professionals or program assistants was 1,060.

Reasons for the shifts in staffing (both increased and decreased) varied from state to state. For instance, some states reported that early retirements, buyouts, downsizing, reclassification, and lost state or county dollars accounted for the declines in staffing numbers. One respondent's comment is illustrative: "Because of decreased state and federal funding, we have replaced

\footnotetext{
${ }^{2}$ This question specifically asked respondents to include all agents with only partial responsibilities for 4-H programming - like single county agents or multi-county agents who give leadership to 4-H in addition to agriculture, community development and family \& consumer sciences.
} 
many former $100 \% 4-\mathrm{H}$ agent positions with program assistants." Another respondent observed how critical funding is to staffing changes: "4-H staffing decreased for a period of time due to lost state dollars; now increasing due to restored state dollars and more leveraged county dollars."

In other cases, staff increases were attributed to administrative vision and leadership, implementation of strategic plans, realignment of FTEs from administrative to county positions, or other restructuring moves that led to increased staffing for $4-\mathrm{H}$. One respondent, for example, reported that the Extension Director "has established a goal of placing a full-time 4-H agent in all counties with a population of 30,000 or more. Currently we are eight counties short of this goal."

There has been a suggestion that the declines in fully-funded academic positions at the state, district and county levels have been due, in part, to an increase in program coordinators or assistants. According to respondents, the number of county agent positions has largely declined since 1990, while the number of program assistants has increased. This trend is born out by the data collected in this survey.

\section{Academic Degree Requirements}

Another purpose of the study was to learn more about the degree requirements for various positions within state Extension programs.

State Level. The vast majority of states require at least a master's degree to work on the state 4-H staff. In all, 72 percent of states have this as a minimum requirement. However, 13 percent require a doctoral degree-some at the time of hire, but others within 6 years of employment.

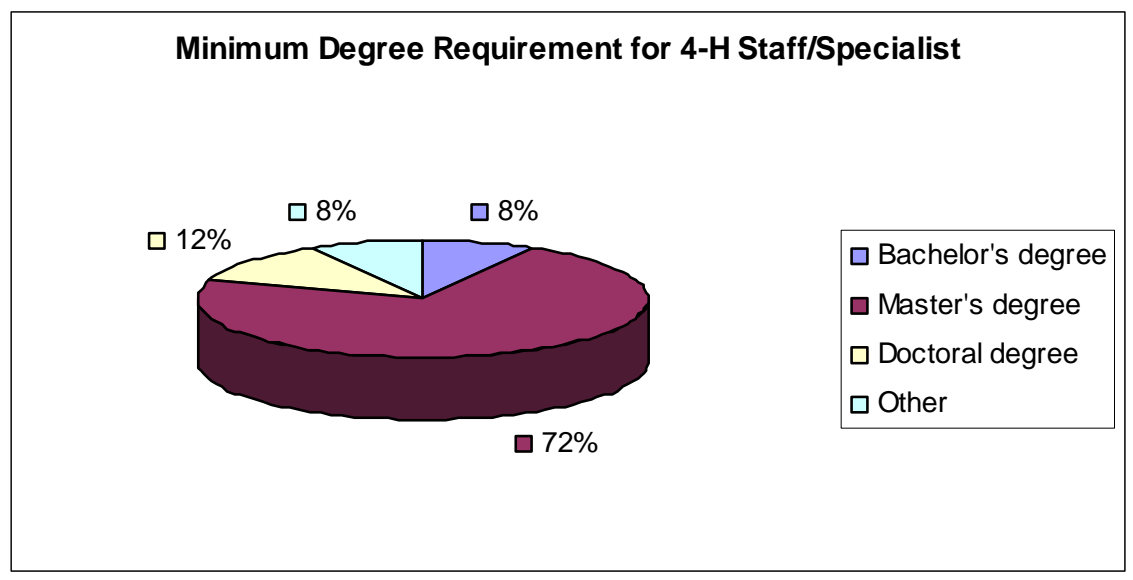

Interestingly, two states reported having no 4- $\mathrm{H}$ specialists of any kind at the state 4-H office. Moreover, 4 states ( 8 percent of the total) reported that only a bachelor's degree was necessary to work on the state staff.

In terms of specific individuals, 28 percent of states (14) have at least one person on the state staff with a doctoral degree while 7 states have no one with such a terminal degree. Thirteen percent have 2 people with doctoral degrees, and 4 states (7 percent) have 6 or more faculty on staff with a doctoral degree. 
For those with master's degrees, 23 percent of states reported having 6 or more individuals with this academic degree on the state staff.

District/Regional Level. While only 13 states reported having a district or area-type structure for 4-H specialists, most require a master's degree for this level of work. In fact, 69 percent (9 states) require a master's degree while four states require only a bachelor's degree.

County 4-H Educators. Nearly two-thirds of the states (58 percent) require a bachelor's degree as the minimum to work as a county agent. Thirty-seven percent require a master's degree, and no states require a doctorate degree for this level of work. Interestingly, two states have

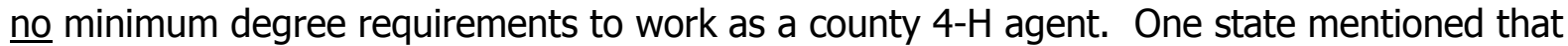
their county agents were "assistants, not educators."

But the lack of consistency of titles and degrees to work in 4-H youth development is evident from the survey responses. In one state, New Jersey, county staffing is quite different. County agents are those with master's degrees and 3 years of experience to start. A program "associate" is someone with a bachelor's degree and 2 years of experience to start. A program assistant is a county-hired para-professional who usually has a bachelor's degree. Salaries for each are different.

We also sought to learn if the degree requirements for doing 4-H youth development were different between the 1862, 1890 and 1994 land-grant universities in each state. In about half of the states, there are no other land-grant universities other than the 1862 institution. However, in the others, 11 percent of respondents reported that the degree expectations were different for Extension agent positions at the other land grant institutions. However, 24 percent said there were no differences in degree requirements between institutions. Curiously, another 17 percent did not know for certain if there were any differences in degree requirements between the institutions.

When queried about whether there were degree differences between 4- $\mathrm{H}$ and other Extension positions in states, 87 percent said there were no differences in academic degrees between $4-\mathrm{H}$ and other positions. However, 11 percent ( 5 states) indicated that there were different academic degree expectations in their states between 4- $\mathrm{H}$ and other county Extension agents.

Because so many states have single- to two-agent county staff configurations, we wanted to learn more about how 4-H programming duties were distributed in the system. Hence, we asked about whether all Extension agents, regardless of their primary responsibilities, had expectations from Extension administration to work in 4-H programming. In about the states (53 percent), the answer was yes. But in 47 percent of the states, the answer was no. Three states skipped this question.

\section{Compensation}

Low compensation levels in youth work have been a major concern for many years (Boyle, 2003). Thus, several survey questions sought to collect information about current salary levels for various $4-\mathrm{H}$ positions. 
State 4-H Specialists. There was a lot of consistency across the system in terms of compensation for state 4-H specialists.

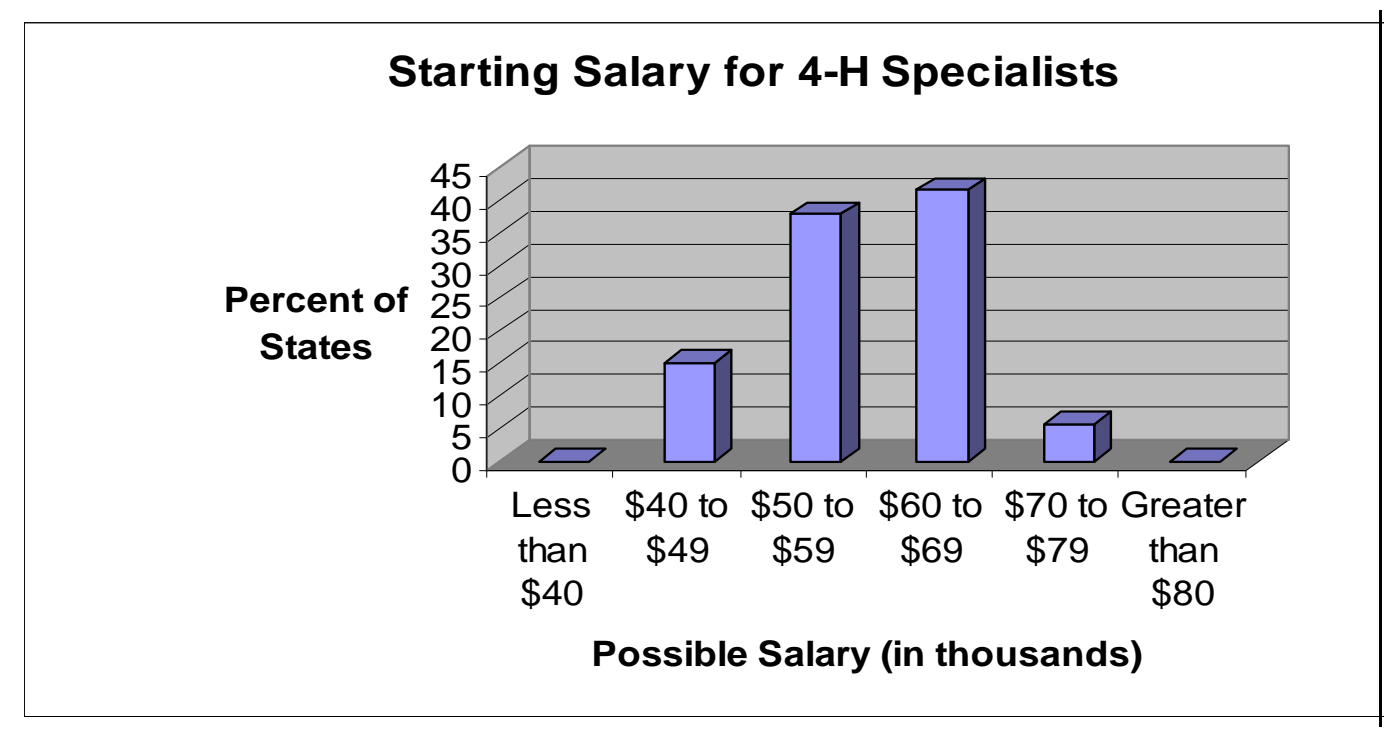

As this table indicates, the majority of states are paying similar levels for specialists with a doctorate, although 3 states are providing significantly higher levels of compensation.

State specialists with master's degrees are typically paid less than state specialists with doctoral degrees. For example, 13 percent of states (6) paid less than $\$ 40,000$ to state specialists with only a master's degree. The majority of states (51 percent) reward master's degree specialists with $\$ 40,000$ to $\$ 49,999$ per year. But 30 percent (16 states) pay their master's degreed specialists $\$ 50,000$ to $\$ 59,999$. Three states paid more than $\$ 60,000$ to specialists with a master's degree.

District/Regional Specialists. Since 75 percent of states do not have regional or district levels of program leadership, salary levels were not as consistent across the system as they were with state specialists. Six states pay less than $\$ 40,000$ per year for their district specialists, while 3 states pay between $\$ 40,000$ and $\$ 49,999$. Four states pay more than $\$ 50,000$ to their district or area specialists.

County 4-H Educators. Not surprisingly, county-based 4-H youth workers are paid typically less than district or state specialists. Nearly two-thirds of states (60 percent) pay $\$ 30,000$ to $\$ 39,999$ per year to county educators. But 17 percent pay less than $\$ 30,000$ per year. Finally, 19 percent pay $\$ 40,000$ to $\$ 49,999$. Two states paid county educators more than $\$ 50,000$ per year. 


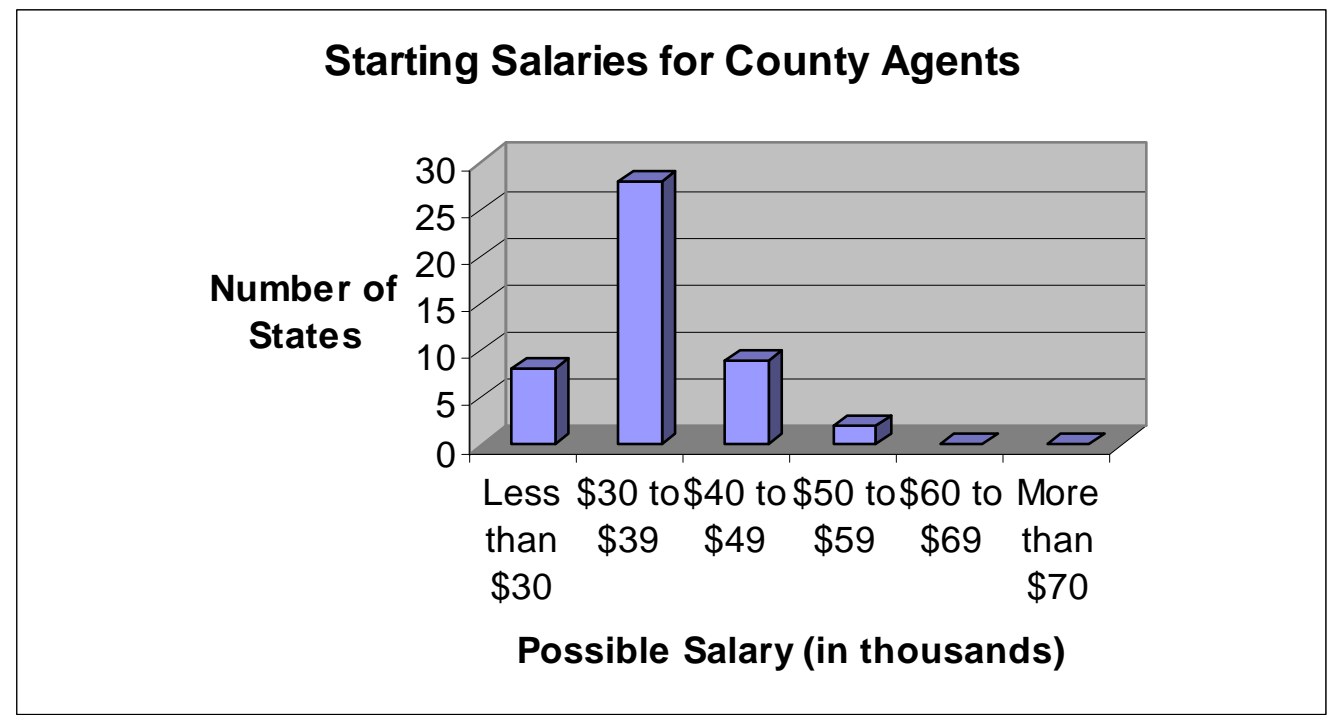

Program Coordinators/Assistants. While one-third of states do not have 4-H program coordinators, those that did paid them at a comparable level to county 4-H educators. Twentyfour percent of states paid 4-H program coordinators $\$ 30,000$ to $\$ 34,999$, while 18 percent paid $\$ 35,000$ to $\$ 39,999$. In a few states, program coordinators are paid $\$ 40,000$ to $\$ 50,000$ per year.

\section{Academic and Other Preparation}

Another section of the survey surveyed respondents about their opinions as to the fields of study and practical experience that would provide the best preparation for working in youth development. A significant portion (43 percent) felt that an academic degree was "essential" to ensuring positive youth development outcomes. Another 49 percent said that a degree was "very important." About 8 percent said that a degree was "somewhat important." No one said that an academic degree was "irrelevant."

The disciplines which state program leaders felt provided the best preparation for youth work were:

- Education--98 percent

- Human development-94 percent

- Child development-90 percent

- Psychology-31 percent

- Animal science-29 percent

- Speech communications-20 percent

Other than academics, state 4-H leaders indicated that the following were areas where other skills were important for working in 4-H youth development:

- Experience working with youth and volunteers

- Conflict resolution

- Communications skills/process skills

- Youth development

- Program management/organization 
Internships were commonly mentioned as valuable training experiences and preparation for working in 4-H youth development.

\section{Best Staffing Models}

Finally, respondents were asked to weigh in on what they felt, from their experience, was the "best" staffing configuration for a modern 4-H program at least with respect to degree requirements.

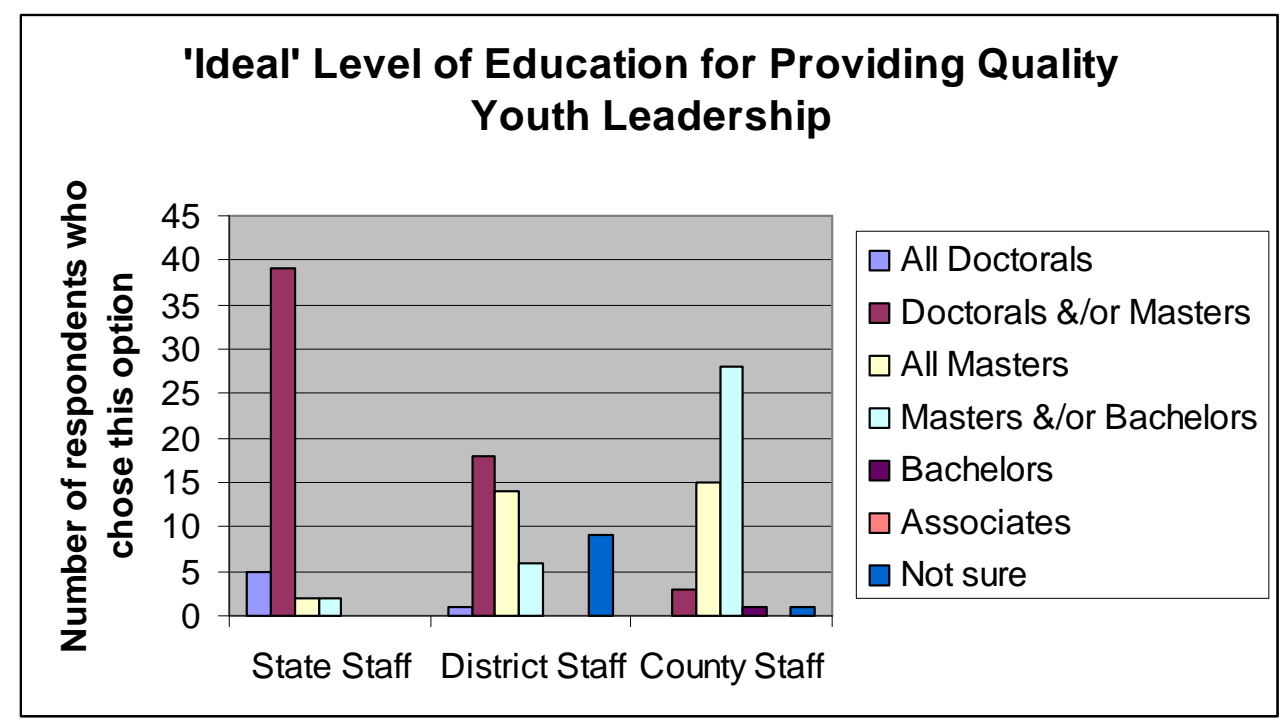

\section{Challenges to 4-H Staffing}

The final question on the survey asked "what is the biggest challenge related to 4-H staffing in your state?" This question was our opportunity to solicit open-ended responses from state leaders about what they saw in the future.

The most common response to this question was lack of adequate funding-17 state program leaders indicated this as a significant challenge. Cuts in state budgets, the difficulty of finding new funding for agent positions, lack of adequate county funding, the inability to offer competitive salaries to qualified candidates, lack of a career ladder, lack of administrative support for 4-H-all were mentioned as challenges to $4-\mathrm{H}$ staffing for the future. One respondent, for example, commented that a significant challenge was "building the case for 4- $\mathrm{H}$ specialists staff as compared to Ag specialist staff."

In several cases, the lack of adequate specialist staff to support county agents was listed as a challenge to 4-H staffing. Some states, as we saw in the findings from the survey, have no 4-H specialists at all at the state level. This lack of critical mass to provide leadership at the state level for program and organizational support, as well as knowledge development, continues to be a significant challenge to leading a modern $4-\mathrm{H}$ program in the $21^{\text {st }}$ century.

\section{Implications and Next Steps}

The findings from this first wave effort to map 4-H youth development staffing in Extension has collected a wealth of useful information that suggest a number of directions for the future and implications. Like other such studies, there is cause of celebration, and yet also cause for concern. 
Salaries and Compensation. Youth workers in Extension tend to fall into the same consistent ranges across the system. Compared with youth workers in private or non-profit organizations, Extension youth workers, as employees of public agencies, are generally compensated at higher levels. The average annual salary of youth workers in the non-profit arena is being paid about $\$ 26,000$ (Light, 2003) while the salary for Extension youth workers is $\$ 30,000$ to $\$ 39,999$. A few states pay even more. These facts should give us a competitive advantage for recruiting, attracting and retaining youth work professionals.

However, some states are very low in compensation for Extension youth professionals. Still, amount of education, geography and organizational size all affect salaries according to recent studies (Boyle, 2006). These factors are clearly true in Extension as well. States could retain their existing trained youth workforce if they could determine how to provide viable career ladders and graduated salary structures that reward excellence.

Professional Status. 4-H youth workers still struggle to attain equal status in the eyes of Extension colleagues and administrators. As our findings revealed, some states do not even have a post-secondary degree requirement for county Extension agents, in a few states they are not identified as educators, and many states indicated that professional or academic status still eludes 4-H professionals. One respondent remarked that the biggest challenge to 4-H staffing was the continuation of a "caste system-no consistent titles, requirements or training." Another was equally direct: "Recognizing youth development as an academic discipline" is the biggest challenge.

McDowell pointed out as much in his book about Extension and the land-grant universities. For a long time, McDowell observed,

"There were no unique qualifications to be a 4-H agent.... The 'bottom of the totem pole' position of 4-H within extension is emblematic of children at the bottom in society generally, not making economic contributions and requiring a lot of work that is not valued because it is unpaid" (McDowell, 2001, p. 157).

At one time, he writes, 4-H agents knew "more about the animals it teaches kids to raise than it does about the kids" (McDowell, 2001, p. 157). But even McDowell recognizes that this is changing and that 4-H staff are now being hired based on their qualifications to do the job and their focus on youth development (McDowell, 2001, p. 158). Yet, recent efforts to emphasize the importance of youth development competencies must still deal with this legacy and some residual history still embraced by some Extension administrators.

Concerns identified in the 1984 study of the image of the 4-H professional appear to not have changed significantly in the intervening years. Youth development still lacks academic respect on campuses and is often not given recognition as a discipline or field of study. There is a lack of consistency of titles, status and job expectations across the Extension system.

Sustaining the Credentials of 4-H Professionals. Our findings suggest that the belief that there has been an erosion in the professional ranks of $4-\mathrm{H}$ youth workers is accurate. A number of states reported that academic, professional educator positions have been slowly replaced with activity managers or program assistants. One respondent mentioned "keeping educator positions" as a challenge to current staffing. This erosion of professional positions appears to 
be more pronounced at the county level rather than at the state or district level. But it is at the county/parish level where frontline youth work occurs and where educational impacts can be documented.

At a time when youth work is becoming more complex and challenging, Extension needs to take measures to increase, rather than decrease, the academic and career preparation standards for frontline 4-H youth workers. A recent study of all professional workers in Montana found that most youth workers had good access to the tools that would help them do their job (e.g. computers, internet, phones, fax, etc.), but training and compensation still seemed to be significant challenges (Astroth, 2006).

Need for Increased Numbers of County 4-H Staff. While 4-H has the benefit of one of the largest cohesive groups of youth professionals, there are limits to how much they can do. The size and scope of the 4-H network is enviable and potential partners for advancing positive youth development can have a high level of assurance that the 4- $\mathrm{H}$ nexus can reach millions of youth quickly through its hundreds of thousands of volunteers like no other group can.

Given the current discussion to double the number of youth in $4-\mathrm{H}$ clubs nationwide, there must be also a concerted effort to increase the number of 4- $\mathrm{H}$ youth development staff-both professional and volunteer. Doubling the number of youth in 4-H clubs will more than double the workload of youth professionals. Doing more with less is not realistic.

Given the reports of burnout and excessive workloads in the youth field already, ways must be found to expand the ranks of professional youth workers and volunteers working in 4- $\mathrm{H}$. Adding more work to the existing staff will potentially increase staff turnover. As the recent Brookings Institute study found, 70 percent of those in their survey strongly or somewhat agreed that they "always have too much work to do" (Light, 2003).

This view was supported in the open-ended comments of several state 4-H program leaders. As one wrote: "It is amazing how much we get done in 4-H Youth Development with such a small staff." Similar comments were made in the recent Alaska 4-H Program Review Final Report (University of Alaska, 2006).

Organizational Support at the State Level for Field Staff Must Be Increased. As our survey revealed, there are several states that have very small or non-existent specialist staff supporting county field faculty. Overall, the ratio of state 4-H specialists to county field faculty is 1-to-5. In addition, the majority of states reported that their state 4- $\mathrm{H}$ staffs were smaller than 15 years ago. Only about a third reported higher numbers of FTEs at the state level.

State level organizational support for field staff from $4-\mathrm{H}$ is much lower than for other program areas of Extension, especially as compared to agriculture. If Extension provides knowledgebased education, then there must be a congruent investment in "knowledge development" at the state 4- $\mathrm{H}$ level by investing in specialist and research staff to support field faculty. In those states where there are no $4-\mathrm{H}$ specialists, or a very small number compared to county $4-\mathrm{H}$ agents, it is difficult to imagine how the 4-H program can remain viable. As McDowell observes: "investments on the campus in support of programs is very important" (McDowell, 2001, p. 152). Some states are not maintaining this investment. 
Retention and Turnover. Several states commented on the high rates of turnover they experienced in 4-H positions. Turnover and retention are common themes in youth development, but there are some specific issues with Extension that have implications for both the short and long-term future. Several states commented on a "generational shift" in 4-H ranks-losing a large number of "baby boomers" to retirement and the positions not being refilled. Another remarked that "I have no staff under the age of 40 so I will have a huge mass retirement over the next 5 years."

In some states, the high cost of living and remote rural locations make it difficult or impossible to find qualified applicants who will accept positions. States like Hawaii, in particular, are challenged in finding degreed applicants who can afford the high cost of living, especially housing. As a result, positions often remain vacant for years, placing an increased workload on existing staff.

This first wave study did not examine job satisfaction issues, turnover or retention strategies, however. We highly recommend that the next phase of this work include questions to examine these issues in 4-H youth development work. The common impression is that there is high turnover and burnout in 4-H work-just as in other youth work fields.

Balancing Program Management and Education Roles. From our study, there are still challenges to $4-\mathrm{H}$ youth professionals who must live in an academic environment and yet must manage a broad array of educational events and activities. It is a challenge to excel in both arenas, and often the day-to-day expectations and immediate demands of program management take precedence over academic, educational responsibilities. Several respondents mentioned the "activity trap" which keeps talented and skilled 4-H professionals from engaging in scholarly work to advance the field of youth development. One individual specifically commented that his challenge was "creating and delivering a 4-H youth development program that addresses the needs of $21^{\text {st }}$ century youth who live in a world of technology and fast-paced educational experiences."

All states are encouraged to reference 4-H PRKC competencies in job announcements and job descriptions. Including these competencies would help identify and give priority to youth development skills necessary for success.

\section{Conclusion}

This first national study of 4-H staffing structures and patterns has provided some muchneeded insight into current staffing and some trend analysis since 1990 . While the erosion in professional positions within 4-H is not as great as some may have suspected, the current study shows that there has been a decline in the number of FTEs at the state level in most states. About one in 10 states have stayed the same size, but notably nearly 30 percent have experienced growth. Factors in this growth have been re-alignments, administrative leadership, and improved budgets.

Still, Extension 4-H youth development provides one of the most extensive networks of youth professionals of any organization in the nation. Our staff is highly trained, well-paid compared to other youth workers. Few others can lay claim to having such a reach and impact as 4-H can. 
However, there has been a shift to hiring more program assistants and coordinators at the county level to replace Extension agents with a bachelor's or master's degree. In some states, the impetus for these changes is due in part to financial considerations. As pointed out above, in about one-fourth of states, program assistants are paid, on average, $\$ 5,000$ to $\$ 10,000$ less than degreed agent educators. Yet, there must be something more at play since in other states program assistants are paid nearly at par with degreed agents. More investigation in this area is clearly warranted.

The impact of these staffing changes on youth development outcomes is not known. Future studies should examine the link between the academic preparation and training of 4- $\mathrm{H}$ youth workers and positive youth development outcomes-a call that was voiced in the National 4-H Research Response Task Force report of 2003 (Blyth and Borden, 2003). In addition, future efforts should examine job satisfaction, retention and turnover within 4-H professional ranks. 


\section{APPENDIX}

\section{Definitions}

All state 4-H programs are different, and titles and position descriptions vary widely. In some states, the same title might mean different things and connote a different status. For the purposes of this study, the following definitions were employed. There was common agreement amongst most states, and so this list provides a useful reference and common language for $4-\mathrm{H}$ positions across the system.

State 4-H Program Leader-these individuals serve as the program administrators for 4-H programs within each state. Sometimes called directors, they provide overall 4-H leadership and provide supervision over state $4-\mathrm{H}$ office personnel and in some cases county $4-\mathrm{H}$ educators. Typically, these individuals are 100 percent administrative but may have a few programmatic responsibilities. They often are considered to be like department heads.

State-level Staff/Specialist-this person typically works with the state 4-H office/center and has state-wide job expectations, they may live elsewhere in the state and not necessarily be housed at the land-grant college. Such a person usually has a terminal degree, but might also have a master's level degree at a minimum. Responsibilities may include developing curriculum, providing program leadership or subject matter duties, teaching others (including agents, volunteers and youth), program development, evaluation, etc. Such a person performs primarily an educational role although event management may comprise some of their time. There may be certain positions that are called "specialist" but which do not perform these functions--such as a food service director or conference center director. Do not include these types of nonteaching positions even though they may be titled as "specialists." State 4-H program leaders should be included in this category. This category does not include support staff or secretarial staff.

Area/Regional/District Specialist-these types of individuals usually have geographicallydetermined responsibilities for $4-\mathrm{H}$, supporting agents, volunteers and leaders through teaching, program development, implementation and evaluation. These individuals could have a terminal degree, but also might possess a master's degree (at a minimum). Like state 4-H specialists, event management and activities are a small part of their responsibilities.

County or parish agent/advisor/educator-these individuals typically work in one or several local jurisdictions providing program leadership, program management and development, and evaluation at a local level. These individuals typically have either a master's or bachelor's degree and are considered educators or faculty within Extension. Events and activities comprise an important part of their job, but are not the exclusive focus.

Program associate, program assistant, coordinator, para-professional, program representative-these individuals typically work under the supervision of an agent/advisor/educator or specialist and their positions do not require a bachelor's degree (although some individuals may possess such a degree) AND these individuals are primarily responsible for conducting events and activities. In some state $4-\mathrm{H}$ offices, these kinds of people are events and activities coordinators. They often do not develop curriculum on their own, but rather teach programs developed by others or conduct events and activities. However, these titles and roles vary from state to county levels. 
Aide-these individuals typically work on a part-time basis with an Extension office and provide clerical or support services (like photocopying, organizing materials for a judging contest, organizing record books to be reviewed, etc.) for others. They do not teach programs, develop or deliver curriculum, although they may assist others at programs and events in a supporting role.

FTE-Full-time equivalent. A standard measure used to calculate staff size which allows several part-time positions to be combined together.

1862 Land-Grants. Land-Grant Institutions Established by the Passage of the First Morrill Act (1862): the Morrill Act was intended to provide a broad segment of the population with a practical education that had direct relevance to their daily lives.

1890 Land Grants. 1890 Land-Grant Colleges and Universities and Tuskegee University: historically black land-grant colleges and universities. Through the Act of August 30, 1890 (the Second Morrill Act), and several other authorities, these institutions may receive Federal funds for agricultural research, extension and teaching.

1994 Land Grants. 1994 Land-Grant Colleges \& Universities [also referred to as Tribal Colleges]: Native American Institutions that received land-grant status in 1994 as a provision in the Elementary and Secondary Education Reauthorization Act, titled "The Equity in Educational Land-Grant Status Act of 1994."

\section{References}

Annie E. Casey Foundation. (2003). The unsolved challenge of system reform: The condition of the frontline human services workforce. Baltimore, MD: Author. Available at:

http://www.aecf.org/upload/PublicationFiles/the\%20unsolved\%20challenge.pdf

Astroth, K.A. (2003). Doorway, doormat or doghouse? The challenges facing 4-H youth development scholarship in land-grant universities. Journal of Extension, 41:6. Available on-line at: http://www.joe.org/joe/2003december/comm1.shtml

Astroth, K.A. (2004). 4-H youth development, scholarship and land-grant universities. Journal of Higher Education Outreach and Engagement, 9:1. pp. 87-102.

Astroth, K.A. (2006). More than child's play: A profile of professional youth workers in Montana. Bozeman, MT: Montana State University, Montana 4-H Center for Youth Development.

Blyth, D.A. \& Borden, L.M. (2003). Stimulating research, promoting youth development: Final report of the national youth development research response initiative. Minneapolis, MN:

University of Minnesota. Available on-line at: http://www.fourh.umn.edu/NYDDRI

Boyle, P. (2006 October). The high passion and low pay of youth work. Youth Today, 15:9. p. 22. 
Eccles, J.A., \& Gootman, J. (Eds.). (2002). Community programs to promote youth development. ashington, D.C.: National Research Council and Institute of Medicine, Board on Children, Youth and Families, Commission on Behavioral and Social Sciences and Education.

Gerhard, G.W. (1984). "The Image of the 4-H Professional." News \& Views, 37:5. pp. 4-8.

Light, P. (2003, March). The Health of the Human Services Workforce. New York, NY: The Center for Public Service, Brookings Institution and the Wagner School of Public Service, New York University. Available on-line at: http://www.brookings.edu/gs/cps/humanservices.pdf

McDowell, G.R. (2001). Land-grant universities and extension into the 21st Century: Negotiating or abandoning a social contract. Ames: Iowa State University Press.

McDowell, G.R. (Personal communication, February 2006).

National Afterschool Alliance (2004). America After 3 PM Survey, pp.1. Available online at: http://www.afterschoolalliance.org/america 3pm.cfm

Sabrosky, L.K. (1963). Attitudes toward 4-H club work, objectives and methods. (PA-597). Washington, D.C.: U.S. Department of Agriculture, Federal Extension Service.

U.S. Department of Education. (1998). Safe and smart: Making the after-school hours count for kids. Washington, D.C.: Author.

University of Alaska. (2006). Alaska 4-H program review-Final report. Fairbanks, AK: Author.

Wessel , T. \& Wessel, M. (1982). 4-H: An American idea--1900-1980. Chevy Chase, MD: National 4-H Council.

Yohalem, N., Pittman, K., \& Moore, D. (2006 July). Growing the next generation of youth work professionals: Workforce opportunities and challenges. Houston, TX: Cornerstones for Kids. Available on-line at: http://www.cornerstones4kids.org/images/next gen final reportRW1.pdf

(C) Copyright of Journal of Youth Development $~$ Bridging Research and Practice. Content may not be copied or emailed to multiple sites or posted to a listserv without copyright holder's express written permission. Contact Editor at: patricia.dawson@oregonstate.edu for details. However, users may print, download or email articles for individual use.

ISSN 2325-4009 (Print); ISSN 2325-4017 (Online) 